\title{
Use of One Cycle of Recurrent Selection per Year for Increasing Resistance to Aphanomyces Root Rot in Peas
}

\author{
Mark E. Lewis ${ }^{1}$ \\ Department of Horticulture, University of Wisconsin, Madison, WI 53706 \\ Earl T. Gritton ${ }^{2}$ \\ Department of Agronomy, University of Wisconsin, Madison, WI 53706
}

Additional index words Aphanomyces euteiches, common root rot, disease resistance, Pisum sativum

\begin{abstract}
The effectiveness of one cycle (C) per year of phenotypic recurrent selection was evaluated for improving tolerance of peas (Pisum sativum L.) to aphanomyces root rot (Aphanomyces euteiches Drech.). Each cycle included field-screening a population of $F_{2}$ lines (summer), diallel intermating among lines selected from the field (fall greenhouse), and one generation of selfing $F_{1}$ plants (spring greenhouse) to produce $F_{2}$ lines for the next cycle. The schedule is repeated for each cycle. A blocks-within-replicates design was employed in the field screening of $\mathrm{C} 1$ and $\mathrm{C2}$ to improve within-block homogeneity. Selection intensities were $12.4 \%, 11.1 \%$, and $10.6 \%$ for $\mathrm{C} 0$, C1, and $\mathrm{C} 2$, respectively. Using the performance of a tolerant control line, Mn 108, as a basis of comparison, the realized gain in dry seed yield and survival was $32 \%$ and $68 \%$ from $\mathrm{C} 0$ to $\mathrm{C} 1$ and $22 \%$ and $115 \%$ from $\mathrm{C} 1$ to $\mathrm{C} 2$, respectively.
\end{abstract}

Aphanomyces root rot of pea, also called common root rot, occurs in most pea-growing areas of North America and in northern Europe, Australia, New Zealand, and Japan (Hagedorn, 1984). The fungus Aphanomyces euteiches was first identified as the causal organism in 1925 (Jones and Drechsler, 1925). Losses in Wisconsin average $\approx 10 \%$ annually (Pfender, 1984), but under conditions of severe disease development, most pea cultivars are killed even before flowering, and entire fields may be lost. Since viable oospores of the organism can exist in the soil for more than 10 years (Pfender, 1984), Gritton et al. (1984) recommended that peas not be grown on the same field more often than once every 4 or 5 years. Although several methods of control have been considered, including the use of cruciferous soil amendments (Muehlchen et al., 1990; Papavizas, 1967), trifuralin and dinitramine herbicides (Harvey et al., 1975), and bacterial seed treatments (Parke et al., 1991), the use of resistant cultivars would also be desirable. To our knowledge, there are currently no cultivars available with high levels of resistance. Moderate resistance or tolerance has been found in certain wild-type lines, but these are associated with an undesirably tall growth habit and colored flowers, which are undesirable because they are often associated with undesired pigment in the shelled pea. This association was attributed to linkage, rather than pleiotropy; many lines found to be susceptible possessed the' same set of dominant alleles (Marx et al., 1972). Breeding lines approaching commercial type and having some resistance to aphanomyces root rot have been released by Washington State Univ. and the U.S. Dept. of Agriculture, Agricul-

Received for publication 8 Oct. 1991. Accepted for publication 27 Mar. 1992. Contribution of the Dept. of Agronomy, Wisconsin Agricultural Experiment Station, Univ. of Wisconsin-Madison. Research supported by funds provided by The College of Agricultural and Life Sciences under project no. 2804 and the Wisconsin Food Processors Assn. Part of a thesis submitted by M.E.L. in partial fulfillment of the requirements for the MS degree at the Univ. of Wisconsin, Madison. Mention of a trademark, proprietary product, or vendor does not constitute a guarantee or warranty of the product by the authors and does not imply its approval to the exclusion of other products or vendors that may also be suitable. The cost of publishing this paper was defrayed in part by the payment of page charges. Under postal regulations, this paper therefore must be hereby marked advertisement solely to indicate this fact.

'Graduate Student.

${ }^{2}$ Professor. tural Research Service (Kraft, 1989; Kraft and Tuck, 1986). Minnesota 108 (Mn 108), a breeding line developed at the Univ. of Minnesota (Davis et al., 1976), has a moderate level of resistance and some desirable commercial qualities, such as a short stature and white flowers. Frequency distributions of resistance in Mn $108 \times$ susceptible crosses indicated little evidence of dominance. A quantitative mode of inheritance with a realized heritability of 0.28 to 0.46 was suggested (Shehata et al., 1983).

Recurrent selection, a breeding strategy involving repeated cycles of selection and intercrossing of superior genotypes, has been widely used in cross-pollinated crops, but has received only limited use in autogamous crops, such as to improve grain and protein yield in oats (Avena sativa L.) (Frey et al., 1988; Payne et al., 1986) and yield (Sumarno and Fehr, 1982) and oil content (Burton and Brim, 1981) in soybean [Glycine max (L.) Merr.]. It has been used to improve resistance to phytopthora root rot in soybean (Walker and Schmitthenner, 1984) and to white mold in common bean (Phaseolus vulgaris L.) (Lyons et al., 1987), and it has been suggested for use in improving resistance to root rot in peas (Shehata et al., 1983). The quantitative nature of the trait, coupled with the association of resistance to undesirable wild-type traits (Mare et al., 1972), suggested that recurrent selection would be the most effective strategy to accumulate favorable factors for resistance. This procedure also would provide an opportunity through repeated intercrossing to break linkages between disease resistance and traits that are undesirable. Field disease screening allows for many replicated families to be tested with minimal effort. Our objective was to evaluate one cycle of phenotypic recurrent selection per year to increase the level of resistance or tolerance to aphanomyces root rot while maintaining or improving agronomic and quality factors.

\section{Materials and Methods}

Plant materials. The base population was formed by use of three groups of germplasm: root rot-resistant breeding lines, standard cultivars, and lines with large root systems. The resis-

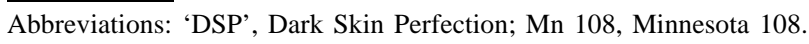


tant breeding lines were formed by intercrossing the following breeding stocks in several double cross (DC) combinations: a) commercial lines 'CSC 8615' and 'CSC 8617' from Canners Seed Corp., Lewisville, Idaho; b) Mn 108 (Davis et al., 1976) and Minnesota 494-All (King et al., 1981) from the Univ. of Minnesota; and c) NY 5 and B275-191, provided by the late G.A. Marx, Cornell Univ., Ithaca, N.Y. The CSC lines were chosen for their agronomic and processing qualities and for possessing powdery mildew resistance, while the other four lines were developed for root rot resistance. After two cycles of evaluation, 14 moderately resistant $\mathrm{F}_{5}$ lines were identified and divided into two groups of seven. Entries in one group were crossed to L1073, 'Badger', and 'CSC 8221', while entries in the other group were crossed to L1532, 'W7101', and an isogenic line (DSP af er) of 'Dark Skin Perfection'.

'Badger', 'CSC 8221', DSP af er, and 'W7101' are lines that were used to introduce desirable processing attributes into the population. 'CSC 8221' has been widely grown in Wisconsin for years; it has some tolerance to aphanomyces root rot. Genes for afila foliage (af) and powdery mildew resistance (er) were introduced through DSP af er. Powdery mildew resistance genes were also introduced through 'CSC 8615', 'CSC 8617', and 'W7101'. Lamprecht Collection (Landskrona, Sweden) lines L1073 and L1532, identified by Veitenheimer (1981) as having especially large root systems, were used in case root rot tolerance might be improved through an increased ability to regenerate roots damaged by the fungus.

$F_{1}$ plants generated in one group were crossed with $F_{1}$ plants of the other group, and the DC $\mathrm{F}_{1}$ plants were grown in root rot-free soil. Of $178 \mathrm{DC} \mathrm{F}_{1}$ plants, 161 were harvested singly; 17 were discarded on the basis of undesirable phenotype. The resulting 161 lines were designated as Cycle 0 (C0). The 20 lines selected from the subsequent field screening of this $\mathrm{C} 0$ base population were intermated in diallel fashion (reciprocals combined) in the fall greenhouse season. Seeds produced from plants selected from the field were used to produce the plants used in crossing. At least three hybridizations (reciprocals pooled) were made per combination and the seed bulked. This ultimately led to the production of $180 \mathrm{~F}_{1}$ bulks (maximum of 190 possible). These $\mathrm{F}_{1} \mathrm{~s}$ were selfed (spring, greenhouse) and then planted in the field as $\mathrm{C} 1 \mathrm{~F}_{2}$ lines to be screened for resistance. Subsequent cycles followed the same pattern of field screening, selection, intermating, and selfing.

Field procedures. Cycles were evaluated in a root rot-infested field nursery located on the Univ. of Wisconsin Agricultural Research Station near Arlington. High levels of the soil-borne fungus $A$. euteiches at this site had resulted from several years of continually cropping peas. Pythium spp. were also present, but $A$. euteiches was determined to be the major cause of root rot (Parke et al., 1991). As a means of visually gauging the uniformity of disease pressure throughout the field, two indicator rows, one the moderately resistant breeding line Mn 108 and one the susceptible cultivar DSP, were planted the length of the field between replicates.

In 1985, the $161 \mathrm{C} 0$ lines were planted on 20 May in plots $61 \mathrm{~cm}$ long, with 10 seeds per plot. Row spacing was $91 \mathrm{~cm}$. The design was a randomized complete block (RCB) with two replicates. Mn 108 and 'DSP' were included five times per replicate as moderately resistant and susceptible controls, respectively. Seeds were treated with $N$ - trichloromethylthio-4-cyclohexene-1,2-dicarboximide (captan) fungicide before planting, and 2-chloro- $N$ - (1-methylethyl)- $N$ - phenylacetamide (ramrod) her- bicide was applied to the soil 1 day after planting. Additional weed control was achieved by hand-hoeing.

In 1986, C1 was planted on 20 May and handled similarly. The design was changed to a blocks-within-replicates $(B / R)$ design (Hallauer and Miranda, 1981) with three replicates of 180 lines. The change from a RCBD was deemed necessary because of the many lines to be evaluated. Lines were randomly assigned to one of six sets, which reduced block size from 180 to 30 . A resistant and a susceptible control plot were included in each block. Because of a dry spring, plots were irrigated once early $\mathrm{n}$ the growing season with $\approx 25 \mathrm{~mm}$ of water to promote disease development.

The screening procedure for C2, planted on 15 May 1987, was similar to that used in 1986. However, because of improved greenhouse lighting, enough $\mathrm{C} 2$ seed was obtained to set out four replicates with 20 seeds per plot. The 189 lines were divided into nine sets of 21 , thereby further reducing block size from 1986 levels. Irrigation was not necessary in 1987.

Evaluation and selection. The primary characters evaluated in each cycle were dry seed yield, the percentage of emerged plants surviving to produce seed, and disease severity of the above-ground portion of the plant rated visually. Disease ratings (Table 1 ) were taken on a plot basis $\approx 60$ days after planting, when symptom expression was generally maximal. Characters of secondary importance included days to $50 \%$ bloom (an indication of maturity), seed type (green, wrinkled desired), plant height, flower color, and powdery mildew resistance.

Data from the $\mathrm{C} 0$ trial were analyzed as a RCBD; $\mathrm{C} 1$ and $\mathrm{C} 2$ data were analyzed as a B/R design via MSTAT version 4.0 (Michigan State Univ.). For the B/R analysis, sources of variation were partitioned as due to replicates $(\mathrm{R})$, sets $(\mathrm{S})$, replicates by sets $(R \times S), B / R$ (derived by pooling the $S$ and $R \times$ $\mathrm{S}$ sources of variation), lines-within-sets, and replicates by lineswithin-sets, i.e., "error." Selection was based first on a comparison with the resistant control (Mn 108) for primary characters (yield, percent survival, and disease rating), and lines better than or equal to the resistant control for all three characters were identified. For the trials using the B/R design, comparisons were made only within sets, and an attempt was made to represent each set when making selections. Secondary char-

Table 1. Description of disease scores for pea symptoms to aphanomyces root rot.

\begin{tabular}{|c|c|}
\hline Score & Description \\
\hline 1 & No disease development \\
\hline 2 & $\begin{array}{l}\text { Slight yellowing of lower leaves on less than one-half } \\
\text { of plants }\end{array}$ \\
\hline 3 & $\begin{array}{l}\text { At least one-half of plants with some yellowing; } \\
\text { pod development nearly normal }\end{array}$ \\
\hline 4 & $\begin{array}{l}\text { More than one-half of plants showing some symptoms; a few } \\
\text { plants dead soon after pod set }\end{array}$ \\
\hline 5 & $\begin{array}{l}\text { Most plants with moderate yellowing and/or wilting, but with } \\
\text { nearly normal pod set; a few plants dying between flowering } \\
\text { and pod set }\end{array}$ \\
\hline 6 & $\begin{array}{l}\text { Most plants showing strong disease development (yellowing } \\
\text { and wilting); about one-half with nearly normal } \\
\text { pod development }\end{array}$ \\
\hline 7 & $\begin{array}{l}\text { About one-half of plants dead at flowering or shortly } \\
\text { thereafter; reduced pod development }\end{array}$ \\
\hline 8 & Most plants dead at flowering or shortly after \\
\hline 9 & All plants dead not long before flowering \\
\hline 10 & All plants dead shortly after emergence \\
\hline
\end{tabular}


acters, such as seed type and bloom date, were used as discriminants in making the final selections. Twenty lines were chosen in each cycle, i.e., $12.4 \%, 11.1 \%$, and $10.6 \%$ of all $\mathrm{C} 0, \mathrm{C} 1$, and C2 lines, respectively, as parents to be crossed to form the next cycle. Seed used for parents of $\mathrm{C} 1$ and $\mathrm{C} 2$ were chosen at random from bulked seed of the selected lines.

Gain from selection. To assess the gain from selection, composites of $\mathrm{C} 1$ were tested in 1986 in the same root rot-infested field used for screening $\mathrm{C} 0$ and $\mathrm{C} 1$. Composites for $\mathrm{C} 0$ and $\mathrm{C} 1$ were prepared by bulking one to two seeds from each line planted in 1985 (C0) and 1986 (C1). Mn 108 was also included as a control in the experiment. The experiment was arranged as a four-replicate RCBD of plots $2.43 \mathrm{~m}$ long, with 48 seeds per plot.

Gain also was assessed by expressing $\mathrm{C} 0, \mathrm{C} 1$, and $\mathrm{C} 2$ means as a percentage of the resistant control mean in 1985, 1986, and 1987, respectively. This method of comparison was valuable because of year-to-year fluctuations in root rot severity. Cycle means were divided by the resistant control mean for that year and multiplied by 100 . For each year and trait combination, therefore, Mn 108 would represent $100 \%$.

\section{Results}

Characterization of cycles. The line means for the primary characters for each cycle (Table 2) are useful for making comparisons within a cycle. Cycle means cannot be compared directly because of year-to-year variation in disease severity, as witnessed by the fluctuations in the resistant control (Mn 108) means. The poor performance of the susceptible control ('DSP'), a commercial cultivar, provides an indication of the high degree of disease pressure present. Plots of this line yielded an average of only $0.2 \mathrm{~g}$ in 1985 and 1986 (Table 2) and often produced no seed.

The mean performance of the lines selected in each cycle (seed yields of 36.6,14.9, and $42.4 \mathrm{~g} /$ plot for $\mathrm{C} 0, \mathrm{C} 1$, and $\mathrm{C} 2$, respectively) and even each population mean (Table 2) compared favorably to the resistant control mean (seed yields of $14.4,5.2$, and $12.4 \mathrm{~g} / \mathrm{plot}$ for 1985, 1986, and 1987, respec- tively, Table 2). The year-to-year fluctuations prevent a direct comparison of date of bloom. However, using the Mn 108 means as a base, the $\mathrm{C} 0$ mean bloom date was slightly later (1.4 days) than that of $\mathrm{Mn} \mathrm{108}$; the mean bloom date for C2 was 5 days earlier than that for Mn 108 (Table 2).

Gain from selection. Expressing cycle means as a proportion of the mean of Mn 108 (Table 3) eliminated much of the yearto-year variation in disease pressure and allows for a direct comparison among cycles. Using this criterion, a gain of $\approx 32 \%$ in dry seed yield was realized from $\mathrm{C} 0$ to $\mathrm{C} 1$ and $68 \%$ from $\mathrm{C} 1$ to $\mathrm{C} 2$. The gain in survival from $\mathrm{C} 0$ to $\mathrm{C} 1$ was good $(22 \%)$ but was very substantial $(115 \%)$ from $\mathrm{C} 1$ to $\mathrm{C} 2$. The visual disease rating showed no consistent trend, worsening from $\mathrm{C} 0$ to $\mathrm{C} 1$, but improving from $\mathrm{C} 1$ to $\mathrm{C} 2$.

The composite study (Table 4) offered a second opportunity to compare cycles, although only $\mathrm{C} 0$ and $\mathrm{C} 1$ were tested. Significant differences between composites were found for dry seed yield, visual disease rating, and days to $50 \%$ bloom. The mean yield of the $\mathrm{C} 1$ composite was more than three times that of $\mathrm{C} 0$ (Table 5). The result for disease rating conflicted with the percentage-of-control comparison, as the mean $\mathrm{C} 1$ rating was more than two points better than the mean $\mathrm{C} 0$ score. Again, $\mathrm{C} 1$ bloomed earlier than $\mathrm{C} 0$.

\section{Discussion}

Although the composite study and the percentage-of-control data both show trends of increasing resistance or tolerance to aphanomyces root rot, each has inherent limitations. Reliance on one genotype (Mn 108) for adjustment can lead to misinterpretation if substantial genotype $\times$ environment interactions are involved. An indication of the existence of this interaction can be found by examining the changes in percent survival of genotypes Mn 108 and 'DSP' from 1986 (48.6\% and 3.1\%, respectively) to 1987 (31.6\% and $13.1 \%$, respectively). The scope of the composite trial was limited; only 1 year and location were used, and each line of $\mathrm{C} 0$ and $\mathrm{C} 1$ was represented by a small amount of seed. However, the composite and adjusted data sets show similar positive trends, particularly in dry seed yield. This

Table 2. Pea seed yield, percent survival, disease rating, and days to $50 \%$ bloom for populations (cycles, C), 20 selected lines, and controls ('DSP' and Mn 108) for $\mathrm{C} 0, \mathrm{C} 1$, and $\mathrm{C} 2$. Pea root rot nursery, Arlington, Wis.

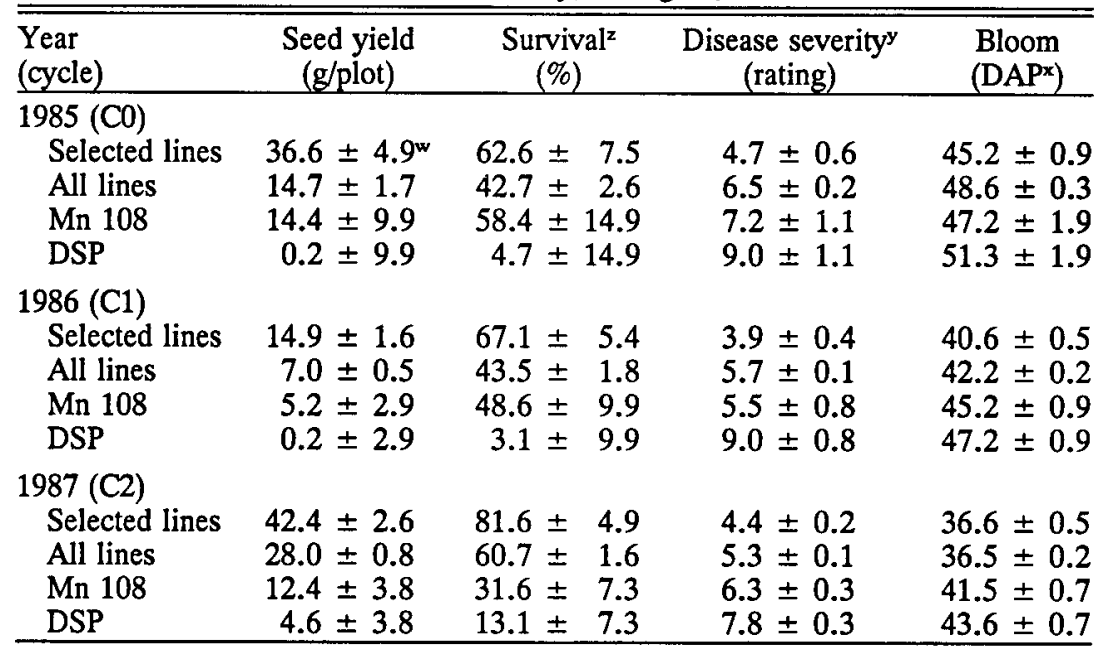

xPercentage of emerged plants surviving through dry seed production.

$\mathbf{y}_{1}=$ no disease, $10=$ all plants dead soon after emergence.

Days after planting (DAP) until $50 \%$ of plants have at least one open flower.

w95\% Confidence interval, where C.I. $=t_{0.025} \sqrt{\mathrm{MSe} / \mathrm{n}}$. 
Table 3. Cycle means for pea root rot resistance evaluation expressed as a percentage of 1985,1986 , and 1987 Mn 108 means, respectively, showing percent progress in parentheses (Arlington, Wis.).

\begin{tabular}{lcccc}
\hline \hline Cycle & Year & $\begin{array}{c}\text { Seed } \\
\text { yield }\end{array}$ & $\begin{array}{c}\text { Percent } \\
\text { survival }\end{array}$ & $\begin{array}{c}\text { Disease } \\
\text { rating }\end{array}$ \\
\hline 0 & 1985 & $102.1 \pm 11.8^{y}$ & $73.1 \pm 4.4$ & $90.3 \pm 2.8$ \\
& & $(+31.8 \%)$ & $(+22.4 \%)$ & $(+14.7 \%)$ \\
1 & 1986 & $134.6 \pm 9.6$ & $89.5 \pm 3.7$ & $103.6 \pm 1.8$ \\
& & $(+67.8 \%)$ & $(+114.6 \%)$ & $(-18.8 \%)$ \\
2 & 1987 & $225.8 \pm 6.4$ & $192.1 \pm 5.1$ & $84.1 \pm 1.6$ \\
\hline
\end{tabular}

${ }^{\mathrm{z}}$ As a point of reference, $\mathrm{Mn} 108=100 \%$ in all cases.

${ }^{y} 95 \%$ Confidence intervals derived by dividing intervals calculated for yearly cycle means by each year's Mn 108 mean.

Table 4. Mean squares for seed yield, percent survival, disease rating, and days to $50 \%$ bloom from the 1986 composite gain from selection study (Arlington, Wis.).

\begin{tabular}{llcrlc}
\hline \hline $\begin{array}{l}\text { Source of } \\
\text { variation }\end{array}$ & df & $\begin{array}{c}\text { Seed } \\
\text { yield }\end{array}$ & $\begin{array}{c}\text { Percent } \\
\text { survival }\end{array}$ & $\begin{array}{c}\text { Disease } \\
\text { rating }\end{array}$ & $\begin{array}{c}50 \% \\
\text { bloom }\end{array}$ \\
\hline Replicates & 3 & 49.01 & 74.04 & 0.16 & 1.48 \\
Composites $^{z}$ & 2 & $1127.28^{*}$ & 363.21 & $4.73^{* *}$ & $22.54^{* *}$ \\
Error & $5^{y}$ & 249.44 & 130.07 & 0.26 & 1.16 \\
\hline
\end{tabular}

${ }^{\mathrm{z}}$ Includes the resistant control line Mn 108.

${ }^{\mathrm{Y}}$ Reduced by one because of the estimation of a missing plot value. Significant at $P=0.10$ or 0.01 , respectively.

Table 5. Mean seed yield, percent survival, disease rating, and days to $50 \%$ bloom for the 1986 composite gain from selection study (Arlington, Wis.).

\begin{tabular}{lcccc}
\hline \hline $\begin{array}{c}\text { Composite } \\
\text { (or control) }\end{array}$ & $\begin{array}{c}\text { Seed yield } \\
\text { (g/plot) }\end{array}$ & $\begin{array}{c}\text { Survival }^{\mathbf{z}} \\
(\%)\end{array}$ & $\begin{array}{c}\text { Disease severity } \\
\text { (rating)y }\end{array}$ & $\begin{array}{c}\text { Bloom } \\
\text { (DAP) }^{\mathbf{x}}\end{array}$ \\
\hline C0 & 13.4 & 29.2 & 5.7 & 44.1 \\
C1 & 43.5 & 46.7 & 3.5 & 40.2 \\
Mn 108 & 16.8 & 36.3 & 4.0 & 44.5 \\
LSD 0.05 & NS & NS & 0.9 & 2.0 \\
-0.10 & 22.5 & NS & 0.7 & 1.5 \\
\hline
\end{tabular}

2Percentage of emerged plants surviving through dry seed production. $y_{1}=$ No disease, $10=$ all plants dead soon after emergence. Days after planting until $50 \%$ of plants have at least one open flower. ${ }^{N}$ Nonsignificant $F$ test.

agreement tends to strengthen the value of the information from both data sets.

The trend towards an earlier date of bloom is likely a result of relying more heavily on dry seed yield than on the visual rating for selecting the best-performing lines; an early genotype that is beginning to senesce naturally may look more diseased at the time of scoring, but may produce a respectable yield. At the same time, later-blooming genotypes may appear more resistant because of the lack of a carbohydrate sink (the developing pods) in these plants. In some cases, disease symptoms do not develop in the above-ground plant parts until a demand, such as pod development, is imposed on the plant.

Even though field disease screening can have certain limitations, the benefits have been substantial overall. Spotty disease development in the field, year-to-year differences in disease pressure caused by variation in temperature and soil moisture, and high cvs are all commonly faced problems. The negative effect of these aspects can be minimized, however, through the use of control genotypes, timely irrigation, and a B/R experiment design that uses the idea of breaking the field into smaller, more homogeneous "grids." The benefits of field screening, including the high degree of disease pressure, the ability to select for field tolerance, and the relatively large amount of field space available for testing on a replicated-family basis, appear to outweigh the negatives.

Based on previous research on the resistance of peas to root rot (E.T. Gritton, unpublished results; Lockwood, 1960; Shehata et al., 1976, 1983), we did not expect the gains to be as rapid as those reported here. Rapid gain could be attributed to one or more factors, including the severe selection pressure imposed by the high level of the fungus at the evaluation site, the intercrossing of the superior genotypes (which not only allowed for an accumulation of resistance genes, but also helped break any linkages between resistance genes and certain undesirable wild-type traits), and the replicated testing of $\mathrm{F}_{2}$ families vs. testing of individuals. Some of the yield increase may be attributed to hybrid vigor. However, since each cycle is at the same stage of heterozygosity $\left(\mathrm{F}_{2}\right)$, the gains from cycle to cycle should be due to accumulation of favorable genes for resistance. The ability to conduct one complete cycle of selection per year makes this system of phenotypic recurrent selection very attractive. The extensive degree of "pre-breeding" that went into the formation of the root rot-resistant parents of the base population and the choice of the particular nonresistant parental germplasm also was important. The rapid initial progress in this improvement effort and the reduction in the selection differentials in $\mathrm{C} 2$ suggests that, at least within the germplasm used, relatively few genes may be playing a major role in improving resistance or tolerance.

\section{Literature Cited}

Burton, J.W. and C.A. Brim. 1981. Recurrent selection in soybeans. III. Selection for increased oil content in seeds. Crop Sci. 21:3134.

Davis, D.W., M.A. Shehata, and H.L. Bissonnette. 1976. Minnesota 108 pea breeding line. HortScience 11:434.

Frey, K.J., J.K. McFerson, and C.V. Branson. 1988. A procedure for one cycle of recurrent selection per year with spring-sown small grains. Crop Sci. 28:855-856.

Gritton, E.T., E.S. Oplinger, and E.E. Schulte. 1984. Commercial pea production. Univ. of Wisconsin Extension Publ. A2346.

Hagedorn, D.J. (ed.). 1984. Compendium of pea diseases. Amer. Phytopathol. Soc., St. Paul.

Hallauer, A.R. and J.B. Miranda, Fo. 1981. Quantitative genetics in maize breeding. Iowa State Univ. Press, Ames.

Harvey, R.G., D.J. Hagedorn, and R.L. DeLoughery. 1975. Influence of herbicides on root rot in processing peas. Crop Sci. 15:67-71.

Jones, F.R. and C. Drechsler. 1925. Root rot of peas in the United States caused by Aphanomyces euteiches (N. SP.). J. Agr. Res. 30:293-325.

King, T.H., D.W. Davis, M.A. Shehata, and F.L. Pfleger. 1981. Minnesota 494-All pea germplasm. HortScience 16:100.

Kraft, J.M. 1989. Registration of 86-638, 86-2197, 86-2231, and 862236 pea germplasm. Crop Sci. 29:494-495.

Kraft, J.M. and J.A. Tuck. 1986. Registration of 75-786, 84-1638, and 84-1930 pea germplasms. Crop Sci. 26:1262-1263.

Lockwood, J.L. 1960. Progress and problems in breeding peas resistant to root rots. Mich. Agr. Expt. Sta. Quart. Bul. 43:358-366.

Lyons, M.E., M.H. Dickson, and J.E. Hunter. 1987. Recurrent selection for resistance to white mold in Phaseolus species. J. Amer. Soc. Hort. Sci. 112:149-152.

Marx, G.A., W.T. Schroeder, R. Provvidenti, and W. Mishanec. 1972. A genetic study of tolerance in pea (Pisum sativum L.) to aphanomyces root rot. J. Amer. Soc. Hort. Sci. 97:619-621.

Muehlchen, A.M., R.E. Rand, and J.L. Parke. 1990. Evaluation of crucifer green manures for controlling aphanomyces root rot of peas. Plant Dis. 74:651-654. 
Papavizas, G.C. 1967. Comparison of treatments suggested for control of aphanomyces root rot of peas. Plant Dis. Rptr. 51:125-129.

Parke, J.L., R.E. Rand, A.E. Joy, and E.B. King. 1991. Biological control of pythium damping-off and aphanomyces mot rot of peas by application of Pseudomonas cepacia or P. fluorescens to seed. Plant Dis. 75:987-992.

Payne, T.S., D.D. Stuthman, R.L. McGraw, and P.P. Bregitzer. 1986. Physiological changes associated with three cycles of recurrent selection for grain yield improvement in oats. Crop Sci. 26:734-736.

Pfender, W.F. 1984. Aphanomyces root rot, p. 25-28. In: D.J. Hagedorn (ed.). Compendium of pea diseases. Amer. Phytopathol. Soc., St. Paul.

Shehata, M.A., D.W. Davis, and H.L. Bissonnette. 1976. A new testing approach for breeding peas resistant to common root rot caused by Aphanomyces euteiches Drechs. J. Amer. Soc. Hort. Sci. 101:257261.

Shehata, M.A., D.W. Davis, and F.L. Pfleger. 1983. Breeding for resistance to Aphanomyces euteiches root rot and Rhizoctonia solani stem rot in peas. J. Amer. Soc. Hort. Sci. 108:1080-1085.

Sumarno, and W.R. Fehr. 1982. Response to recurrent selection for yield in soybeans. Crop Sci. 22:295-299.

Veitenheimer, E. 1981. Pea (Pisum sativum L.) root growth and development as affected by genotype, media, and Aphanomyces euteiches Drechs. MS Thesis, Univ. of Wisconsin, Madison.

Walker, A.K. and A.F. Schmitthenner. 1984. Recurrent selection for tolerance to phytopthora rot in soybean. Crop Sci. 24:495-197. 